\title{
Pattern of oral and dental diseases among children attending Dental dept. in Dhaka Shishu (Children) Hospital, Dhaka, Bangladesh: A cross sectional hospital based study
}

\author{
Dr. Mohammad Ali ${ }^{1^{*}}$
}

\section{AFFILIATION:}

\section{Dr. Mohammad Ali}

Assistant Professor, Dentistry,

Dhaka Shishu Hospital, Bangladesh

E-mail: ali.mohammad3500@gmail.com

\section{Article info.}

Received: 5 July 2020

Accepted: 18 September 2020

Volume: Vol-10, Issue-2, October 2020

DOI:

https://doi.org/10.3329/updcj.v10i2.50173

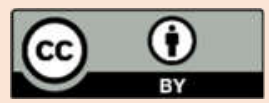

(c) Authors retain copyright and grant the journal right of first publication with the work simultaneously licensed under Creative Commons Attribution License CC - BY 4.0 that allows others to share the work with an acknowledgment of the work's authorship and initial publication in this journal.

https://creativecommons.org/licenses/by/4.0/

Publisher: Update Dental College, Dhaka, Bangladesh

Web: www.updatedentalcollege.edu.bd

E-mail: updcj@hotmail.com

* Corresponding Author

Dr. Mohammad Ali

Assistant Professor, Dentistry, Dhaka Shishu Hospital, Bangladesh

E-mail: ali.mohammad3500@gmail.com

Contact No: +8801707271054

\section{Citation}

Ali M. Pattern of oral and dental diseases among children attending Dental dept. in Dhaka Shishu (Children) Hospital, Dhaka, Bangladesh: A cross sectional hospital based study. UpDCJ;10(2): 6-9

DOI: https://doi.org/10.3329/updcj.v10i2.50173

\begin{abstract}
:
Introduction: Oral and dental health isthe standard of the oral and related tissue, which enables an individual to eat, speak, and socialize without active discomfort and embarrassment and which contributes to general well-being of the individual.Objective: To find out Pattern of oral and dental diseases among children attending Dental Department in Dhaka Shishu (Children) Hospital, Dhaka, Bangladesh.Materials and Methods:This was a cross sectional hospital based study carryout among 443 childrens ( 242 males and 201 females) attending in the Department of Paediatric dentistry in Dhaka Shishu (Children) Hospital.All the new patients attending to Dental OPD with the complained of oral and dental problems were included in this study. Old patients and those who were not willing to participate in the clinical examination for study were excluded from the study. The study period was October 2018 to December 2018.Results: The study was carried out among (443) children were 242 (54.6\%) males and 201 (45.4\%) females a male-female ratio of 1.2:1.The age range of children were $224(50.6 \%)$ below the, age of 5 years, $200(45.1 \%)$ at the age of $5-10$ years and $19(4.3 \%)$ above 10 years (1014 years). Out of 443 children 157 (22.7\%) showed presence of dental caries, $138(19.9 \%)$ had grossly destructed carious teeth, $79(11.5 \%)$ had dentolveolar abscess, 53 (7.7\%) had retained broken root, 52(7.6\%) were suffering from pulpitis, $108(15.7 \%)$ of the children presented with stomatitis, $34(4.8 \%)$ had retained decidous teeth,24(3.5\%) geographical tongue , 24(3.5\%) oral thrush, $7(1.0 \%)$ gingivitis $7(1.0 \%)$ presented with traumatic injury of tooth, soft tissue and bony tissue, $4(0.5 \%)$ had pericoronitis, $1(0.1 \%)$ had natal tooth and $4(0.5 \%)$ were others like extra oral swelling, apthus ulcer, mucoceale. The total Association of dental disease with different age $<5$ years $45.5 \%, 5-10 \mathrm{yrs}$. $50.1 \%$ and $>10 \mathrm{yrs} .4 .4 \%$. Among them Caries disease all group average high rate so $\mathrm{p}$-Value $(0.010 *)$. So grossly destructed due to caries 49 cases of 5 yrs. $35.5 \%$, 85 cases of $5-10 y$ rs. $54.1 \%$, and 7 cases of under $15 y$ rs. $5.1 \%$ significant.Conclusion: Dental caries was the most predominant disease in the children followed by dentoalveolar abscess. Oral health promotion and planning programs directed towards the oral health should be conducted at regular intervals.
\end{abstract}

Key words: Children, dental caries, dentoalveolar abscess, oral diseases.

Introduction:

Oral and dental health isthe standard of the oral and related tissue, which enables an individual to eat, speak, and socialize without active discomfort and embarrassment and which contributes to general well-being of the individual [1]. Neglect of oral disease in children frequently lead to serious general health problems significant pain, and interference with eating, overuse of emergency rooms and lost school time. [2] It has been estimated 51 million school hours per year are lost because of dental related illness alone [3]. Oral and dental diseases are common in the developing countries. The pattern of these diseases very from on community tol another, and depends on various factors like oral health care practice the level of dental awareness. With sufficient manpower, availability of modern dental equipment and a wide range of dental materials, oral health care for the child has improved in the past three decade. This has been attributed to advances in technology [4]. American academy of pediatric dentistry 
(AAPD) recommends that a child should visit the oral and dental health center with the appearance of the first tooth, typically at 6 months but not letter than 1 year of age[5]. During this visit the developing occlusion should be monitored throughout eruption at regular clinical intervene [6]. It has been shown that pre-school children who visited the oral and dental health center early will more likely visit for preventive reasons as adult[7]. Epidemiological studies have shown that the prevalence of dental diseases particularly dental caries is on the steady increase in developing countries as refined sugar, sweets and fruits drinks Lave become more available[811]. Currently dental carries has become a serious problem in school children and periodontal disease is wide spread in adult population[12]. The purpose of the study is to assess the pattern of distribution of oral and dental diseases among children aged 1 month to 14 years visiting the hospital within a 3 months' time period. The objectives of this research were to identify the major and oral dental problems prevalent in the children so as to plan preventive programs according to their need.

Objective

To find out Pattern of oral and dental diseases among children attending Dental Department in Dhaka Shishu (Children) Hospital, Dhaka, Bangladesh.

Materials and Methods

This was a cross sectional hospital based study carryout among 443 childrens (242 males and 201 females) attending in the Department of Paediatric dentistry in Dhaka Shishu (Children) Hospital.All the new patients attending to Dental OPD with the complained of oral and dental problems were included in this study. Old patients and those who were not willing to participate in the clinical examination for study were excluded from the study. The study period was October 2018 to December 2018.All the patients were examined clinically and investigations were carried out for the required cases. The demographic data, pattern of oral and dental diseases were recorded. Data were analyzed by chi-squared test by using SPSS Windows version 22.

Results

The study was carried out among (443) children patients who were attending in the dental OPD of Dhaka Shishu (Children) hospital during the period of October 2018 to December 2018. There were $242(54.6 \%)$ males and $201(45.4 \%)$ females a male-female ratio of 1.2:1.The age range of children were 224 (50.6\%) below the, age of 5 years, $200(45.1 \%)$ at the age of 510 years and $19(4.3 \%)$ above 10 years (10-14 years) are shown in Table 1 to 2.

\begin{tabular}{llc}
\hline Age group & Frequency & Percentage (\%) \\
\hline$<5$ yrs. & 224 & 50.6 \\
\hline $5-10$ yrs. & 200 & 45.1 \\
\hline$>10$ yrs. & 19 & 4.3 \\
\hline Total & 443 & 100.0 \\
\hline Mean \pm SD Range & & $4.85 \pm 2.77$ \\
& & $(0.20-13.0)$ years \\
\hline
\end{tabular}

Table-1: Age Distribution of the Children $(n=443)$

Table- 1 shows the highest number of child patient's cases in below 5 year. 224 $(50.6 \%)$ and 10 year out of 443 patients count above.
Table-2: Sex Distribution of the Children ( $n=443)$

\begin{tabular}{llc}
\hline Sex & Frequency & Percentage $(\%)$ \\
\hline Male & 242 & 54.6 \\
Female & 201 & 45.4 \\
Total & 443 & 100.0 \\
Male: female ratio & & $1.2: 1$
\end{tabular}

Table-2 shows highest number of patients were male.

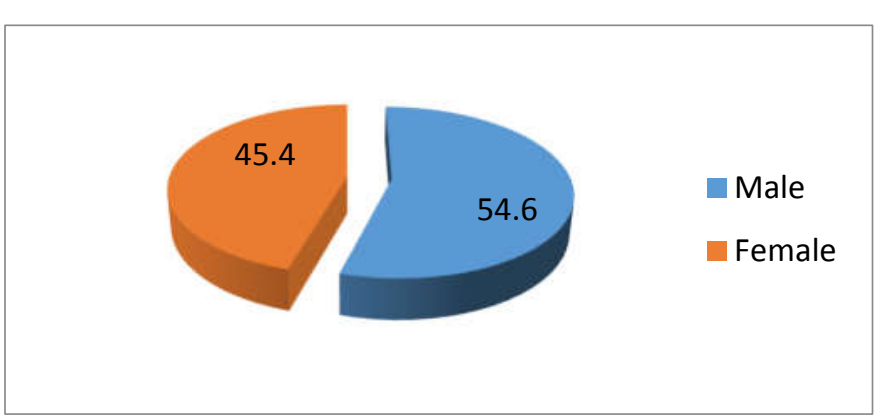

Figure-1: Pie diagram showing the sex distribution of the study subjects.

Table-3: Distribution of the study subjects by dentition $(n=433)$

\begin{tabular}{ccc}
\hline Dentition & Frequency & Percentage (\%) \\
\hline No dentition & 37 & 8.4 \\
\hline Primary dentition & 248 & 56.0 \\
\hline Mixed dentition & 150 & 33.9 \\
\hline Permanent dentition & 8 & 1.8 \\
\hline Total & 443 & 100.0 \\
\hline
\end{tabular}

Table-3 shows out of 443 patients 36 patients (8.4\%) have no dentition 248 (56.0\%) were only primary duration 150 (33.5\%) were mixed dentition and 8 $(1.8 \%)$ were fully permanent dentition. Among them primary dentition group is highest number 228 (56.0\%).

\begin{tabular}{l} 
Table-4: Distribution of the study subjects by dental disease (n=443) \\
\begin{tabular}{|l|c|c|}
\hline Dental disease & Frequency; & $\begin{array}{c}\text { Percentage } \\
\text { (\%) }\end{array}$ \\
\hline Caries & 157 & 22.7 \\
\hline Grossly destructed due to caries & 138 & 19.9 \\
\hline Stomatitis & 108 & 15.7 \\
\hline Dento alveolar abscess & 79 & 11.5 \\
\hline B.D.R & 53 & 7.7 \\
\hline Pulpities & 52 & 7.6 \\
\hline Retained deciduous teeth & 34 & 4.8 \\
\hline Geographical tongue & 24 & 3.5 \\
\hline Oral thrush & 24 & 3.5 \\
\hline Gingivitis & 7 & 1.0 \\
\hline Traumatic injury of tooth soft tissue & 7 & 1.0 \\
\hline bony tissue & & \\
\hline Pericoronities & 4 & 0.5 \\
\hline Natal teeth & 1 & 0.1 \\
\hline Others & 4 & 0.5 \\
\hline Totle & 692 & $(100 \%)$ \\
\hline
\end{tabular} \\
\hline
\end{tabular}

Table-4 shows the pattern and distribution of oral and dental disease seen in children.Out of 443 children 157 (22.7\%) showed presence of dental caries, $138(19.9 \%)$ had grossly destructed carious teeth, $79(11.5 \%)$ had dentolveolar abscess, $53(7.7 \%)$ had retained broken root, 52(7.6\%) were suffering from pulpitis, $108(15.7 \%)$ of the children presented with stomatitis, $34(4.8 \%)$ had retained decidous teeth,24(3.5\%) geographical tongue , $24(3.5 \%)$ oral thrush, $7(1.0 \%)$ gingivitis $7(1.0 \%)$ presented with traumatic injury of tooth, soft tissue and bony tissue, $4(0.5 \%)$ had pericoronitis, $1(0.1 \%)$ had natal tooth and $4(0.5 \%)$ were others like extra oral swelling, apthus ulcer, mucoceale. 


\begin{tabular}{|c|c|c|c|c|c|c|}
\hline $\begin{array}{l}\text { Age } \\
\text { group } \\
\mathrm{s}\end{array}$ & $n$ & $\begin{array}{l}\text { No } \\
\text { dentitio } \\
n N(\%)\end{array}$ & $\begin{array}{l}\text { Primary } \\
\text { dentition } \\
\mathrm{N}(\%)\end{array}$ & $\begin{array}{l}\text { Mixed } \\
\text { dentition } \\
N(\%)\end{array}$ & $\begin{array}{l}\text { Permane } \\
\text { nt } \\
\text { dentition } \\
\mathrm{N}(\%)\end{array}$ & $\begin{array}{l}p- \\
\text { value }\end{array}$ \\
\hline$<5$ & $\begin{array}{l}22 \\
4\end{array}$ & $\begin{array}{l}25(11.2 \\
\%)\end{array}$ & $\begin{array}{l}192(85.7 \\
\%)\end{array}$ & $7(3.1 \%)$ & $0(0.0 \%)$ & $\begin{array}{l}<0.001 \\
*\end{array}$ \\
\hline $\begin{array}{l}5-10 \\
\text { yrs. }\end{array}$ & $\begin{array}{l}20 \\
0\end{array}$ & $\begin{array}{l}12(6.0 \% \\
)\end{array}$ & $\begin{array}{l}55(27.5 \% \\
)\end{array}$ & $\begin{array}{l}\text { 132(66.0 } \\
\%)\end{array}$ & $1(0.5 \%)$ & \\
\hline $\begin{array}{l}>10 \\
\text { yrs. }\end{array}$ & 19 & $0(0.0 \%)$ & $1(5.3 \%)$ & $\begin{array}{l}11(57.9 \% \\
1\end{array}$ & $7(36.8 \%)$ & \\
\hline Total & $\begin{array}{l}44 \\
3\end{array}$ & $\begin{array}{l}37(8.3 \% \\
)\end{array}$ & $\begin{array}{l}248(55.9 \\
\%)\end{array}$ & $\begin{array}{l}150(33.9 \\
\%)\end{array}$ & $8(1.9 \%)$ & \\
\hline
\end{tabular}

Figures in the parentheses indicate corresponding percentage;

Chi-squared Test $\left(\chi^{2}\right)$ was done to analyze the data, ${ }^{*}=$ significant

Table-6: Association of dental disease with different age group ( $n=443$ )

Diseases Age Group p-value

\begin{tabular}{|c|c|c|c|c|c|}
\hline $\begin{array}{l}\text { Dental } \\
\text { disease }\end{array}$ & $\mathrm{n}$ & $<5$ yrs. & 5-10 yrs. & $>10$ yrs. & $0.010^{*}$ \\
\hline Caries & 157 & $65(41.4 \%)$ & $85(54.1 \%)$ & $6(3.8 \%)$ & $0.001 *$ \\
\hline $\begin{array}{l}\text { Grossly } \\
\text { destructed } \\
\text { due to caries }\end{array}$ & 138 & $49(35.5 \%)$ & $82(59.7 \%)$ & $7(5.1 \%)$ & $0.001 *$ \\
\hline Stomatitis & 108 & $83(76.8 \%)$ & $22(20.1 \%)$ & $3(2.8 \%)$ & $0.705^{\mathrm{ns}}$ \\
\hline $\begin{array}{l}\text { Dento } \\
\text { alveolar } \\
\text { abscess }\end{array}$ & 79 & $37(46.8 \%)$ & $39(49.4 \%)$ & $3(3.8 \%)$ & $<0.001^{*}$ \\
\hline B.D.R & 53 & $10(18.9 \%)$ & $40(75.5 \%)$ & $3(5.7 \%)$ & $0.010^{*}$ \\
\hline Pulpities & 52 & $16(30.8 \%)$ & $33(63.5 \%)$ & $3(5.8 \%)$ & $<0.001^{*}$ \\
\hline $\begin{array}{l}\text { Retained } \\
\text { deciduous } \\
\text { teeth }\end{array}$ & 34 & $0(0.0 \%)$ & $31(91.2 \%)$ & $3(8.8 \%)$ & $0.001^{*}$ \\
\hline $\begin{array}{l}\text { Geographical } \\
\text { tongue }\end{array}$ & 24 & $21(87.5 \%)$ & $2(8.3 \%)$ & $1(4.2 \%)$ & $0.014^{*}$ \\
\hline Oral thrush & 24 & 19(79.2\%) & $5(20.8 \%)$ & $0(0.0 \%)$ & $0.509^{115}$ \\
\hline Gingivities & 7 & $5(71.4 \%)$ & $2(28.6 \%)$ & $0(0.0 \%)$ & $0.735^{\text {ns }}$ \\
\hline $\begin{array}{l}\text { Traumatic } \\
\text { injury of } \\
\text { tooth soft } \\
\text { tissue bony } \\
\text { tissue }\end{array}$ & 7 & $4(57.1 \%)$ & $3(42.9 \%)$ & $0(0.0 \%)$ & $0.101^{\text {ns }}$ \\
\hline Pericoronities & 4 & $2(50.0 \%)$ & $1(25.0 \%)$ & $1(25.0 \%)$ & $0.474^{115}$ \\
\hline Others & 4 & $2(50.0 \%)$ & $2(50.0 \%)$ & $0(0.0 \%)$ & $0.613^{\text {ns }}$ \\
\hline Natal teeth & 1 & $1(100.0 \%)$ & $0(0.0 \%)$ & $0(0.0 \%)$ & \\
\hline Total & 692 & $315(45.5 \%)$ & $347(50.1 \%)$ & $30(4.4 \%)$ & \\
\hline
\end{tabular}

Figures in the parentheses indicate corresponding percentage;

Chi-squared Test $\left(\chi^{2}\right)$ was done to analyze the data, ns =not significant, * significant

The total Association of dental disease with different age $<5$ years $45.5 \%, 5-10$ yrs. $50.1 \%$ and $>10$ yrs. $4.4 \%$.Among them Caries disease all group average high rate so $\mathrm{p}$-Value(0.010*). So grossly destructed due to caries 49 cases of 5 yrs. $35.5 \%, 85$ cases of $5-10 y$ rs. $54.1 \%$, and 7 cases of under $15 y$ rs. $5.1 \%$ significant and all patients are another case diasease.It was also seen that the prevalence of dental caries was somewhat similar among males (80.5\%) and females (80.8\%). But the younger children aged between 1 to 6 years showed more dental caries (85.5\%) than the older children of 7 to 14 years (78.5\%). However, this difference was not statistically significant $(p=0.11)$. Amongst the total children who reported in the hospital, $18.4 \%$ reported to the hospital after there was an evident facial swelling or draining pus from the sinus. They reported that they had experienced pain in the past due to caries, but did not seek dental treatment.

Discussion

This study was conducted to evaluate the pattern of distribution of oral and dental diseases in children in Dhaka Shishu (Children) Hospital. In this study, the predominant oral disease was found to be dental caries in $22.7 \%$ and its sequelae like grossel) carious teeth $19.9 \%$, dent alveolar abscess $-11.5 \%$ BDR $7.7 \%$ and pulpitis $7.6 \%$. The next prevalence of oral diseases is oral piucosal disease like stomatitis- $15.7 \%$, geographical tongue $3.5 \%$ and oral thrush-3.5\%,Gingivitis $1.0 \%$,Traumatic injury of tooth soft tissue bony tissue $1.0 \%$,Pericoronities $0.5 \%$, Natal teeth $0.1 \%$ and other diasese $0.5 \%$.Dental caries attributes to toothach and eventually children have to miss their school which will lead to poor performance of children in school. Severe dental decay was the main dental factor related to school absence in Thai children. [13] (Jurpati-Khothmory [6]. World health Organization reports $60-90 \%$ of school children worldwide have] experienced caries, with the disease being most prevalent in Asian and Latin American countries. 14 (jorpitiKhathmory 3).It was also seen that the prevalence of dental cariesl and its sequelae like grosly carious teeth, pulpitis, dentoalveolar abscess, (retained broken root was more in the age group of 5 to 10 years old child than the age group below 5 years. Dental caries is also known to be commonest cause of tooth loss because most patients presents with advanced dental decay for which restorative treatment will not be possible. Complications arising from late presentation include dental abscess, grossly broken \$own crown, retained broken roots and osteomyelitis in severe cases.World Health Organization reports $60-90 \%$ of school children worldwide have experienced caries, with the disease being most prevalent in Asian and Latin American countries [15].It was also seen that the prevalence of dental caries was somewhat similar among males (54.6\%) and females (45.4\%). But the younger children aged between 1 to 5 years showed more dental caries $(85.7 \%)$ than the older children of 7 to 10 years (66.0\%). Out of 443 children 157 (22.7\%) showed presence of dental caries, 138 (19.9\%) had grossly destructed carious teeth, 79 (11.5\%) had dentolveolar abscess, 53 (7.7\%) had retained broken root, $52(7.6 \%)$ were suffering from pulpitis, $108(15.7 \%)$ of the children presented with stomatitis, 34 (4.8\%) had retained decidous teeth,24(3.5\%) geographical tongue , $24(3.5 \%)$ oral thrush, $7(1.0 \%)$ gingivitis $7(1.0 \%)$ presented with traumatic injury of tooth, soft tissue and bony tissue, $4(0.5 \%)$ had pericoronitis, $1(0.1 \%)$ had natal tooth and $4(0.5 \%)$ were others like extra oral swelling, apthus ulcer, mucoceale.The total Association of dental disease with different age $<5$ years $45.5 \%, 5-10$ yrs. $50.1 \%$ and $>10$ yrs. $4.4 \%$. Among them Caries disease all group average high rate so $\mathrm{p}$-Value $\left(0.010^{*}\right)$. So grossly destructed due to caries 49 cases of 5 yrs. $35.5 \%, 85$ cases of $5-10 y r s .54 .1 \%$, and 7 cases of under $15 y$ rs. $5.1 \%$ significant.However, this difference was not statistically significant $(p=0.11)$. This is in accordance with the prevalence studies in Nepal which showed that younger children presented with more dental caries than older 
children. Lonim et al and B Subedi et al in their study have reported that 5-6 yrs. old had caries $52 \%$ and $69 \%$ whereas 12 13 years old children had $41 \%$ and $53.23 \%$ caries prevalence respectively in Nepalese population.[3,7]Amongst the total children who reported in the hospital, $18.4 \%$ reported to the hospital after there was an evident facial swelling or draining pus from the sinus. They reported that they had experienced pain in the past due to caries, but did not seek dental treatment. $41.4 \%$ of children aged $1-5$ years and $49.4 \%$ of the children aged 6-10 years presented with dento-alveolar abscess. This difference was found to be statistically significant $(p<0.05)$. Azodo CC et al have also reported that the untreated dental caries was the most common cause of dentoalveolar abscess in children, followed by trauma, failed restoration or periodontal infection [16]. The patients who visited the dental OPD considered the physiological mobility of the tooth as a major problem in the children. Shows out of 443 patients 36 patients $(8.4 \%)$ have no dentition $248(56.0 \%)$ were only primary duration 150 (33.5\%) were mixed dentition and 8 $(1.8 \%)$ were fully permanent dentition. Among them primary dentition group is highest number $228(56.0 \%)$. The prevalence of malocclusion has increased in recent decades $[17,18]$.Motivational factor for these patient was found to be esthetics, however, they were not aware of the functional or periodontal problems $[17,18]$. This can be explained by the high frequency of falls seen in younger children resulting in trauma to the primary teeth [19]. Traumatic injuries in primary teeth is commonly more in children aged between 13 and 24 months [20].It was also seen that the prevalence of dental caries was somewhat similar among males (80.5\%) and females (80.8\%). But the younger children aged between 1 to 6 years showed more dental caries $(85.5 \%)$ than the older children of 7 to 14 years (78.5\%). However, this difference was not statistically significant $(p=0.11)$. Amongst the total children who reported in the hospital, $18.4 \%$ reported to the hospital after there was an evident facial swelling or draining pus from the sinus. They reported that they had experienced pain in the past due to caries, but did not seek dental treatment.

\section{CONCLUSION}

In this study dental caries was seen to be the most prevalent oral disease among children of 1 to 10 years above of age. Therefore, it can be derived from this study that priority should be given to the treatment and control of dental caries so as to decrease the prevalence of oral diseases as a whole. Rehabilitative care targeted towards treatment of the existing problems of dental caries should be made available to the children. Along with this, oral health education programs at individual, and community levels should be implemented aimed primarily at increasing the knowledge and awareness of the communities towards the risk factors associated with oral problems in order to prevent further increase of occurrence of dental caries among children. A significant $95.4 \%$ of the children made symptomatic visit. Periodontal disease was the most prevalent finding followed by dental caries. There is an urgent need to increase dental health awareness among children through Hospital based continuing dental tips and also among other pediatric care givers such as parents and pediatricians.

\section{REFERENCES:}

1. Department of Health. An oral Health. An oral health strategy for England London: department of Health; 1994.

2. Edmund M, Coye NJ. America's Children: Health Insurance and Access to Care. Washington: National Academy Press; 1998. p. 44-6.

3. United State Department of Health and Human Services (USDHHS). Oral Health in America: A Report of the Surgeon General. Executive Summary. Rockville MD: US Department of Health and HuJnan Services, National Institute of Dental and Craniofacial Research, National Institutes of Health, 2000.

4. Ajike SO, Aroti ba JT, Adebola RA, Ladehinde A, Amole IO. Spectrum of Oral and Maxillofacial Surgical Procedures in Kano, Nigeria. West Indian Med J 2004; 53(Suppl. 6):9-12.

5. American Academy of Pediatric Dentistry: Oral health policies. Pediatric Dentistry 18:24-9, 1996.

6. Council on Clinical Affairs. Guideline on periodicity of examination, preventive dental service, antipatotry guidance/couselling and oral treatment for infants, children and adolescent. Available from: http://www. aapd.org/media/ policies_Guideline/G_Periodicity.pdf. [Accessed 2012 Nov 16].

7. Enwonwu CO. Socio-economic factors in dental caries prevalence and frequency in Nigerians: an epidemiological study. Caries Res 1974; 8:15571.https://doi.org/10.1159/000260104 PMid:4525913

8. Henshaw NE, Adenubi JO. The increase in dental disease in the Northern States of Nigeria and its rfianpower implicati ons. J Dent 1975; 3:243-56. https://doi.org/10.1016/0300-5712(75)90029-9

9. Jeboda SO, Ogunbodede EO. Dental carids in Africa. Nig Qt J HospMed 1994; 5:57-62.

10. Noar J, Portnoy S. Dental status of children in a primary and secondary school in Zambia. Int Dent J 1991; 41: 142-8.

11. Ana JR. Dental manpower need in a developing community: a critical analysis of the West African scene. Int Dent II 1976; 26:411-20.

12. Krisdapong S, Prasertsom P, Rattanarangsima K, Sheiham A. School absence due to toothache associated with socio-demographic factors, dental caries status, and oral health-related quality of life in 12- and 15year-old Thai children. J Public Health. Dent. 2013 Aug 19. doi: 10.1111/jphd.12030.https://doi.org/10.1111/jphd.12030 PMid:24032357

13. Prasai Dixit et al.: Dental caries prevalence, oral and health knowledge and practice among indigenous Chepang school children of Nepal. BMC Oral Health 2013.13:20. https://doi.org/10.1186/1472-6831-13-20 PMid:23672487 PMCid:PMC3655880

14. Prasai Dixit et al.: Dental caries prevalence, oral health knowledge and practice among indigenous Chepang school children of Nepal. BMC Oral Health 2013 13:20. https://doi.org/10.1186/1472-6831-13-20 PMid:23672487 PMCid:PMC3655880

15. Azodo CC, Chukwumah NM, Ezeja EB. Dentoalveolar abscess among children attending a dental clinic in Nigeria. Odontostomatol Trop. 2012 Sep; 35(139):41- 6.

16. Aldrees A M. Pattern of skeletal and dental malocclusions in Saudi orthodontic patients. Saudi Med J 2012; Vol. 33 (3): 315-320.

17. Vibhute AH, Vibhute NA, Daule R. Prevalence of malocclusion characteristics and chief motivational factor for treatment in orthodontic patients from Maharastara, India. J Orthod Res 2013; 1; 62-5 https://doi.org/10.4103/2321-3825.116285

18. Kovács, Mónika, et al. "Prevalence of Traumatic Dental Injuries in Children Who Attended Two Dental Clinics in Târgu Mureo between 2003 and 2011." Oral health and dental management 11.3 (2012): 116.

19. Costa, V. P. P., et al. "Traumatic dental injuries in primary teeth: severity and related factors observed at a specialist treatment centre in Brazil." European Archives of Paediatric Dentistry (2013): 1-6.

Website: https://www.banglajol.info/index.php/UpDCJ 